\title{
Perancangan Alat Ukur Sudut Tekuk Lutut Wireless menggunakan Sensor Gyroscope berbasis ATMega 328 dan ATMega 2560
}

\author{
TEGUH PERKASA, HENDI HANDIAN RACHMAT \\ Jurusan Teknik Elektro Institut Teknologi Nasional \\ Email : tghperkasa@gmail.com
}

\begin{abstract}
ABSTRAK
Pada penelitian ini, sensor Gyroscope digunakan sebagai alat pengukur sudut lutut. Pengukuran sudut ini dilakukan untuk mendiagnosis penyakit pada pasien yang mengalami gangguan atau cedera lutut dan evaluasi pola jalan manusia. Alat pengukur sudut ini terdiri dari 3 sistem yaitu sistem tungkai bawah, sistem tungkai atas dan sistem komunikasi data. Media komunikasi data yang digunakan adalah radio frekuensi 2,4 GHz untuk mentransfer data sudut lutut antar sistem secara wireless. Sensor Gyroscope ditempelkan pada suatu divais mekanik berbahan acrylic sebagai representasi sistem tungkai kaki bawah dan sistem tungkai kaki atas. Kedua sensor tersebut digunakan untuk mengukur percepatan sudut dari kedua sistem tungkai kaki. Kemudian data tersebut diolah menjadi nilai sudut lutut menggunakan kontroler berbasis Arduino. Pengujian alat ini mencakup pengujian sistem tungkai bawah, sistem tungkai atas dan sistem komunikasi data. Dari hasil pengujian diperoleh nilai error sebesar 3 derajat untuk sistem tungkai bawah dan 2 derajat untuk sistem tungkai atas terhadap hasil pengukuran dengan goniometer yang biasa digunakan untuk mengukur sudut lutut oleh tenaga medis. Sistem komunikasi data wireless juga telah berhasil mengirimkan data sudut secara utuh.
\end{abstract}

Kata Kunci: Arduino, Gyroscope, Radio Frekuensi, Sudut lutut, Wireless.

\begin{abstract}
Gyroscope sensor was used to measure a knee angle. The angle measurement is useful to diagnose an early symptom of some patient with disorders or knee injuries as well as to evaluation of gait analysis. The device consist of three system i.e. lower limb system, upper limb system and communication. The radio frequency of $2.4 \mathrm{GHz}$ was used to transfer knee angle data between two systems. Gyroscope sensor were affixed on upper and lower part of the mechanical hinge device that built from acrylic. These device device was representative of the knee joint. Both sensors were used to measure the angular acceleration between the upper part and lower part of leg. The data is then processed into value-based knee angle using Arduino controller. All three system were tested to measure the lower limb angle and the upper limb angel. The results showed that error angle measurment of the lower limb and upper limb are 3 degrees and 2 degrees, respectively, relative to a goniometer measurement as a standard non electronics tool to measure the knee angle. In addition, the data was also successfully transferred wirelessly.
\end{abstract}

Keywords: Arduino, Gyroscope, Radio Frequency, Knee angle, Wireless. 


\section{PENDAHULUAN}

Pengukuran mekanika sendi tulang tubuh manusia seperti sendi lutut merupakan salah satu parameter yang digunakan oleh tenaga medis untuk mendiagnosa kondisi pasien yang memiliki keluhan nyeri atau cedera lutut. Biasanya pengukuran ini tanpa menggunakan alat khusus, tetapi hanya estimasi saja.

Sebenarnya, informasi ini perlu diukur secara lebih tepat karena dapat menjadi informasi yang sangat berguna bagi tenaga medis seperti dokter spesialis ortopedi dan traumatology dalam mendiagnosa cedera dan memberikan terapi bagi pasien secara tepat. Dari penelitian yang telah dilakukan diperoleh bahwa sudut tekuk lutut pasien yang memiliki penyakit Osteoarthritis (OA) memiliki sudut yang lebih kecil dibandingkan dengan pasien normal dilihat dari cara berdiri (stance) dan pada posisi berjalan (swing) (McCarthy, dkk, 2013).

Data sudut tekuk lutut yang diukur ketika seseorang berjalan dengan lambat atau cepat dan berlari pada suatu rentang waktu tertentu, dapat digunakan untuk menganalisa pola jalan (gait analysis). Pola jalan merupakan suatu gerakan yang melibatkan koordinasi akurat berbagai organ tubuh yang dikontrol oleh susunan saraf pusat, dimana di dalamnya mengandung karakteristik ritme, irama, langkah, jarak langkah dan kecepatan (Faried, 2012). Dengan menganalisis cara berjalan pasien maka dapat diketahui juga adanya cedera pada lutut pasien. Dari hasil penelitian Kaufman dan rekan diperoleh bahwa pola jalan seorang pasien yang mengalami cedera akan berbeda (berubah) dikarenakan untuk menahan rasa sakit akibat cederanya (Kaufman, dkk, 2001).

Selain itu, ukuran sudut tekuk lutut ini diperlukan juga bagi pasien untuk melakukan proses terapi lutut pasca melakukan pembedahan atau pengobatan lainya. Proses terapi ini dilakukan dengan melatih kaki pasien dengan cara menekuk dan meluruskan sendi lutut secara bertahap dan berkesinambungan yang dimulai dari sudut fleksi lutut terkecil. Biasanya hal ini dilakukan dengan bantuan seorang perawat atau ahli terapis. Namun, proses terapi ini masih dilakukan secara manual dan tanpa alat ukur lutut yang dapat melakukan pengukuran secara kontinyu atau kaki pasien dalam kondisi bergerak. Tenaga medis atau terapis masih mengukur sudut tekuk lutut menggunakan Goniometer, dimana pengukuran hanya dapat dilakukan oleh alat ini dengan mengharuskan kaki pasien dalam posisi diam. Hal ini tentu saja menjadi sulit untuk memperoleh data kemampuan pergerakan lutut pasien dalam kondisi melakukan pergerakan seperti jongkok-berdiri, duduk-berdiri atau berjalan. Dengan melihat kondisi ini, maka dianggap perlu untuk mendesain suatu alat ukur yang dapat mengukur dan merekam sudut tekuk lutut secara kontinyu.

Pada penelitian sebelumnya telah diimplementasikan alat ukur sudut tekuk lutut dengan menggunakan sensor Inertial Measurement Unit (IMU) dengan ketelitian 10 derajat dan pengiriman data masih menggunakan media kabel (Derry, 2016). Dari penelitian ini diketahui bahwa penggunaan media kabel untuk mengirimkan data mempengaruhi pergerakan lutut pasien dan ketelitian hasil pengukuran masih dapat lebih ditingkatkan. Dari hasil penelitian tersebut, maka penelitian saat ini ditujukan untuk melakukan pengembangan alat ukur sudut tekuk lutut dengan ketelitian 5 derajat dan dapat mengirimkan hasil pengukuran ke dalam suatu kontroler secara wireless. Ketelitian 5 derajat ini menyesuaikan dengan proses pengujian sistem terhadap skala yang mudah dibaca pada alat ukur Goniometer sebagai alat ukur referensi. 


\section{METODOLOGI DAN PERANCANGAN ALAT}

\subsection{Metodologi Penelitian}

Untuk mengimplementasikan sistem alat ukur sudut tekuk lutut wireless ini terdapat beberapa tahapan yang harus dilaksanakan. Gambar 1 memperlihatkan tahapan yang akan dipaparkan. Tahapan yang akan dilakukan dalam penelitian ini seperti ditunjukkan pada Gambar 1, diawali dengan studi literatur untuk mencari sistem yang paling tepat untuk diimplementasikan, sampai pada pengambilan keputusan apakah alat ini sudah sesuai dengan spesifikasi dan fungsi yang diinginkan.

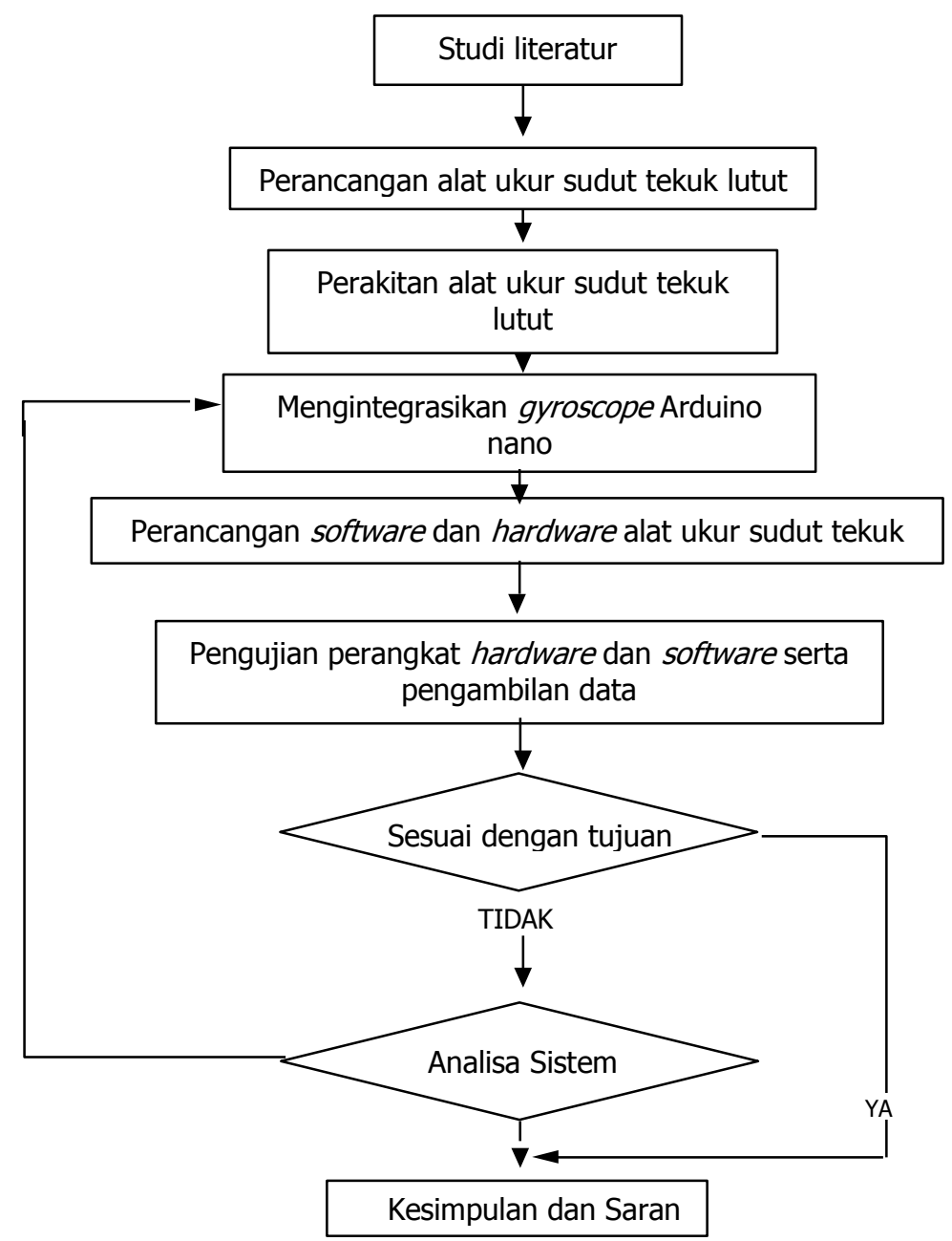

Gambar 1. Metodologi penelitian sistem alat ukur sudut tekuk lutut wireless

\subsection{Deskripsi dan Spesfikasi Sistem}

Diagram blok sistem alat ukur sudut tekuk lutut wireless yang diimplementasikan pada penelitian ini ditunjukkan pada Gambar 2. Sistem ini terdiri dari sejumlah modul perangkat keras dan perangkat lunak. Modul perangkat keras sistem ini terdiri dari dua buah sensor Gyroscope GY-521, tiga buah kontroler berbasis Arduino Nano dengan chip Atmega 328, sebuah kontroler sistem receiver berbasis Arduino Mega dengan chip Atmega 2560 dan empat buah modul komunikasi NRf24I01 sebagai komunikasi wireless menggunakan radio frekuensi 2,4 GHz. Semua perangkat lunak diimplementasikan pada setiap kontroler dan PC (Personal Computer). 


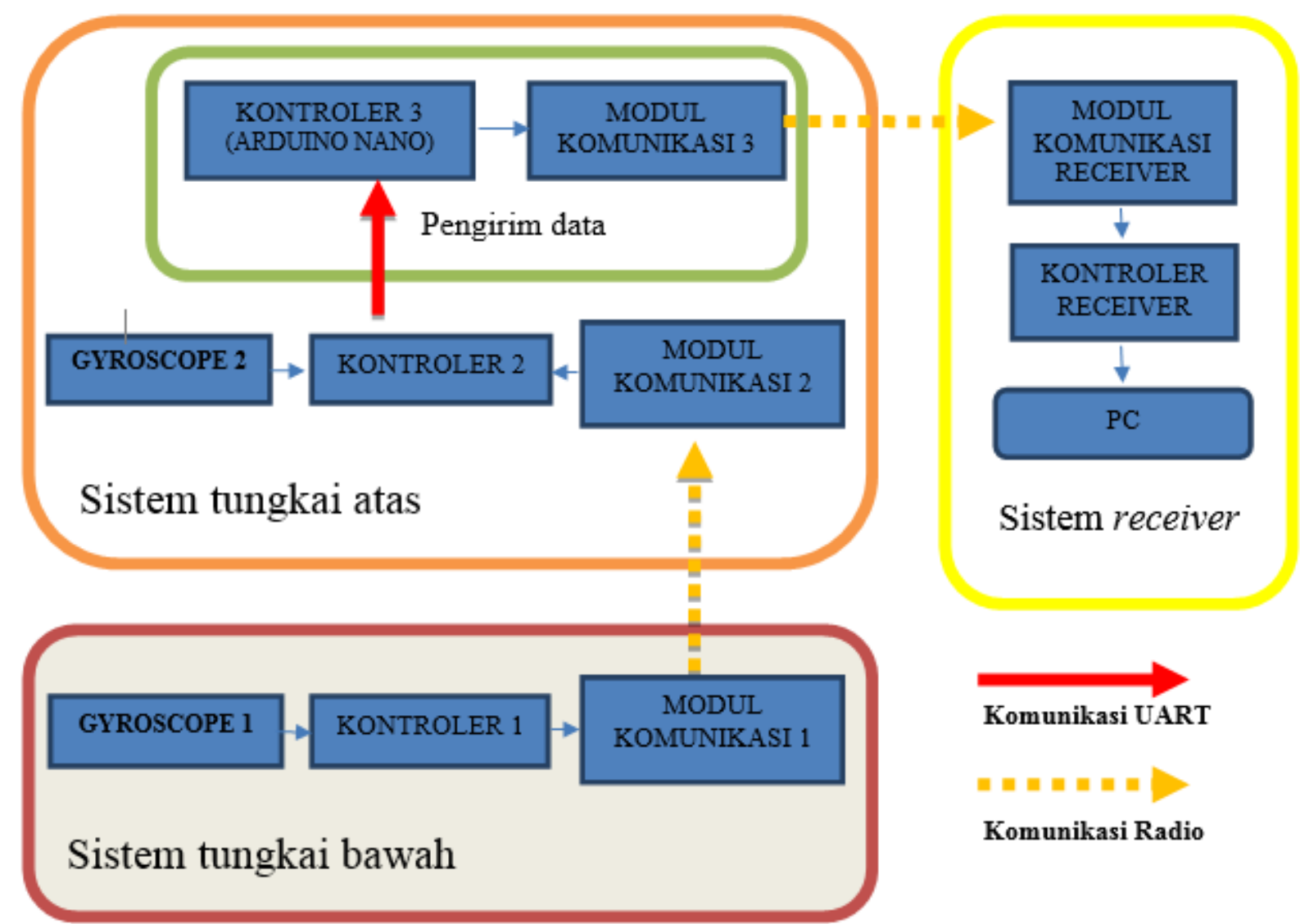

\section{Gambar 2. Blok diagram sistem alat ukur sudut tekuk lutut}

Secara sederhana sistem ini memiliki cara kerja sebagai berikut: data percepatan sudut dari sensor Gyroscope 1 (sistem tungkai bawah) yang terhubung dengan kontroler 1 diolah menjadi data sudut tungkai bawah (Otungkai bawah) dan kemudian dikirimkan menuju kontroler 2 melalui modul komunikasi 1 dan modul komunikasi 2. Data percepatan sudut dari sensor Gyroscope 2 diolah menjadi data sudut tungkai atas (Otungkai atas) di kontroler 2. Data sudut dari tungkai bawah dan tungkai atas kemudian dihitung di kontroler 2 untuk mendapatkan sudut lutut dengan menggunakan persamaan (1) sebagai berikut:

$$
\text { sudut lutut }=180^{\circ}-(\text { ttungkai atas }+ \text { ttungkai bawah })
$$

Data sudut lutut yang telah dihtiung di kontroler 2 selanjutnya dikirimkan ke kontroler 3 melalui sistem komunikasi UART (Universal Asyncrhonous Receiver Transmitter). Kemudian data dari kontroler 3 dikirimkan ke kontroler receiver melalui modul komunikasi 3 dan modul komunikasi receiver. Data sudut lutut yang telah diterima oleh kontroler receiver selanjutnya ditampilkan pada monitor PC menggunakan fasilitas serial monitor yang terdapat pada software arduino IDE. Komunikasi data antara kontroler receiver dengan PC menggunakan fasilitas USB to Serial.

Adapun spesifikasi alat yang akan diimplementasikan pada penelitian ini adalah sebagai berikut:

a) Modul Gyroscope yang digunakan sebagai sensor untuk mengukur sudut adalah sensor tipe GY-21 dengan chip MPU6050.

b) Nilai yang diambil dari sensor adalah nilai percepatan sudut pada sumbu $Y$ sebagai sumbu rotasi (Gambar 3), kemudian diubah menjadi nilai Pitch pada kontroler Arduino. 


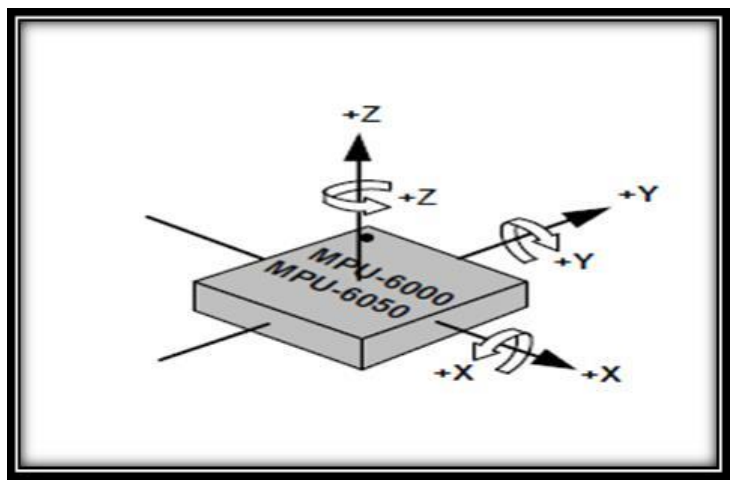

Gambar 3. Sumbu-sumbu rotasi pada sensor inertial chip MPU-6050 (Taryana dkk, 2015)

c) Kontroler berbasis Arduino Nano dan Arduino Mega digunakan untuk mengolah data dari Gyroscope.

d) Modul komunikasi NRf24I01 digunakan untuk mengirimkan data sudut menggunakan frekuensi radio $2,4 \mathrm{GHz}$.

e) Catu daya untuk sistem adalah 9 volt.

f) Nilai presisi kurang dari 2 derajat simpangan.

g) Ketelitian alat 5 derajat.

h) Range sudut pada penelitian antara 180(posisi kaki tegak) - 55 derajat.

\subsection{Metoda Perancangan dan Realisasi Alat}

Metoda perancangan ini terdiri dari metoda perancangan dan realisasi perangkat keras dan perangkat lunak.

\subsubsection{Perancangan dan Realisasi Perangkat Keras}

Pada perancangan perangkat keras terdiri dari tiga sistem yaitu sistem tungkai bawah, sistem tungkai atas dan sistem receiver. Hal ini dilakukan karena pada penelitian ini digunakan 2 buah sudut acuan untuk menghitung sudut tekuk lutut yaitu sudut yang dibentuk paha terhadap lutut dan sudut yang dibentuk tungkai bawah terhadap lutut. Sistem receiver berfungsi untuk menampilkan data sudut lutut pada layar monitor secara wireless.

\subsubsection{Realisasi Sistem Tungkai Bawah}

Sistem tungkai bawah terdiri dari satu sensor Gyroscope GY-521, satu buah kontroler berbasis Arduino Nano (kontroler 1), modul komunikasi NRf24l01 dan sebuah catu daya 9 volt. Sistem ini berfungsi untuk membaca sudut dari tungkai bawah terhadap lutut. Data sudut lalu dikirim menuju sistem tungkai atas. Dimensi sistem dibuat seminimum mungkin untuk diletakan di tungkai bawah agar tidak mempengaruhi ayunan kaki pada swing phase. Skematik diagram sistem tungkai bawah diperlihatkan pada Gambar 4. 


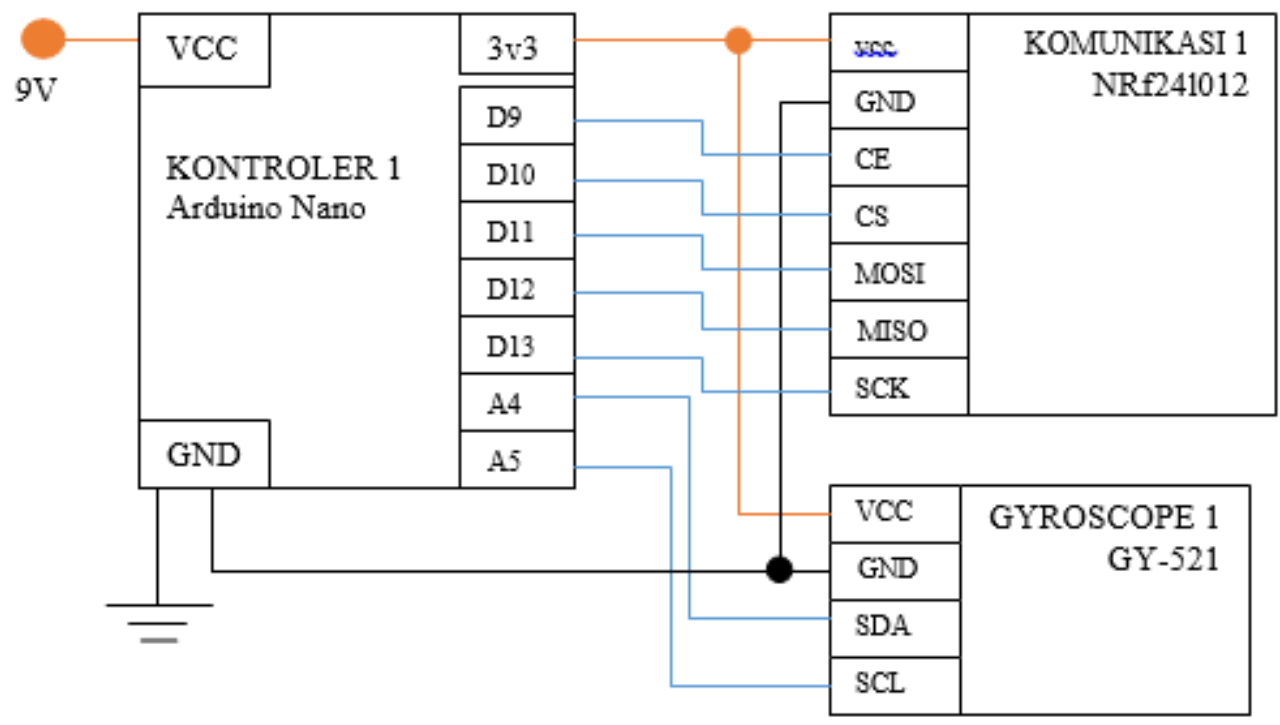

Gambar 4. Skematik diagram sistem tungkai bawah

Komunikasi I2C (Inter-Integrated Circuit) digunakan untuk memperoleh data percepatan sudut dari Gyroscope 1 dengan menghubungkan pin SDA(Serial Data) dan SCL(Serial Clock) pada Gyroscope ke pin A4 dan A5 pada Arduino Nano. Lalu data percepatan sudut yang telah diterima oleh kontroler 1 diolah menjadi data sudut tungkai bawah. Kemudian untuk mengirimkan data sudut tungkai bawah melalui NRf24I01 digunakan komunikasi SPI (Serial Peripheral Interface) yaitu dengan menghubungkan secara berurutan pin $\mathrm{CE}$ (Chip Enable), CS(Chip Select), MOSI(Master Output Slave Input), MISO(Master Input Slave Output) pada modul NRf24I01 ke pin D9, D10, D11, D12, D13 pada pin Arduino Nano. Pada Gambar 5 ditunjukan hasil realisasi dari sistem tungkai bawah.

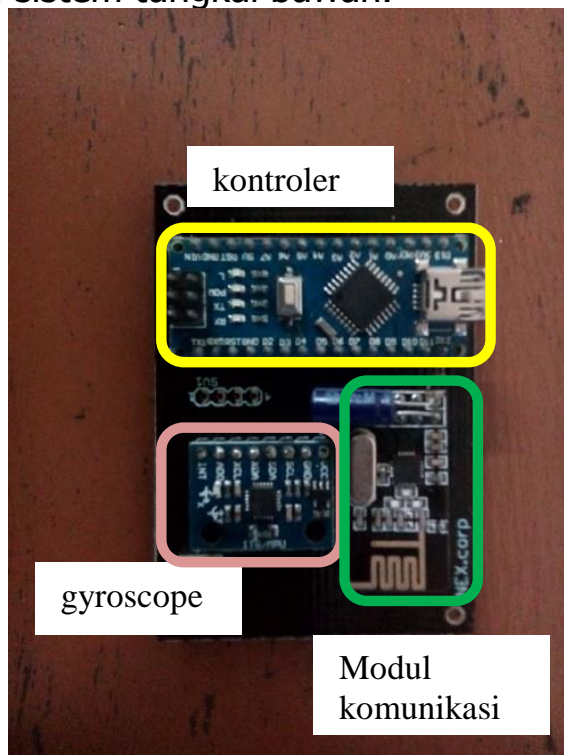

Gambar 5. Realisasi sistem tungkai bawah

\subsubsection{Perancangan dan Realisasi Sistem Tungkai Atas}

Sistem tungkai atas adalah sistem yang dipasang pada bagian tungkai atas kaki (paha) dimana sistem ini menghitung sudut antara tungkai atas dengan lutut dengan Persamaan (1). Sistem ini juga berfungsi untuk menerima data sudut dari sistem tungkai bawah dan menghitung sudut lutut dengan persamaan (1), lalu mengirimkannya ke sistem receiver 
melalui modul komunikasi 3 dan modul komunikasi receiver. Data percepatan sudut yang diterima oleh kontroler diambil dari sensor Gyroscope GY-521 dengan komunikasi I2C kemudian diolah menjadi data sudut tungkai atas.

Pada sistem tungkai atas digunakan dua buah kontroler Arduino Nano. Kontroler kedua untuk menerima data dari sistem tungkai bawah dan kontroler pertama untuk mengirim data ke receiver yang sudah terhubung ke PC. Hal ini dilakukan agar data yang dikirim ke receiver hanya satu data, karena dapat terjadi collision apabila receiver menerima data dari sistem tungkai atas dan sistem tungkai bawah secara bersamaan, sehingga data yang diterima ditampilkan secara acak. Hal ini mengakibatkan kesalahan dalam perhitungan dalam Persamaan (1).

Data Sudut tungkai bawah yang dikirim melalui modul komunikasi 1 diterima oleh modul komunikasi 2 kemudian dikirimkan ke kontroler 2 melalui komunikasi SPI dengan menghubungkan secara berurutan pin CE, CS, MOSI, MISO pada modul komunikasi 2 ke pin D9, D10, D11, D12, D13 pada kontroler 2. Kemudian untuk mendapatkan data percepatan sudut dari Gyroscope 1 digunakan komunikasi I2C dengan menghubungkan pin SDA dan SCL pada Gyroscope 1 dengan pin A4 dan A5 pada kontroler 2. Selanjutnya data percepatan sudut diolah menjadi data sudut tungkai atas oleh kontroler 2. Kemudian data sudut tungkai atas dan data sudut tungkai bawah diolah menjadi data sudut lutut pada kontroler 2 menggunakan Persamaan (1).

Kemudian data sudut lutut dikirim ke kontroler 3 menggunakan komunikasi UART dengan menghubungkan secara berturut-turut pin D0 (Tx), D1 (Rx), GND pada kontroler 2 ke pin D1 (Rx), D0 (Tx), GND pada kontroler 3 (Gambar 6). Selanjutnya data sudut lutut dikirimkan menuju sistem receiver melalui modul komunikasi 3 secara wireless dengan menggunakan frekuensi radio $2,4 \mathrm{GHz}$.

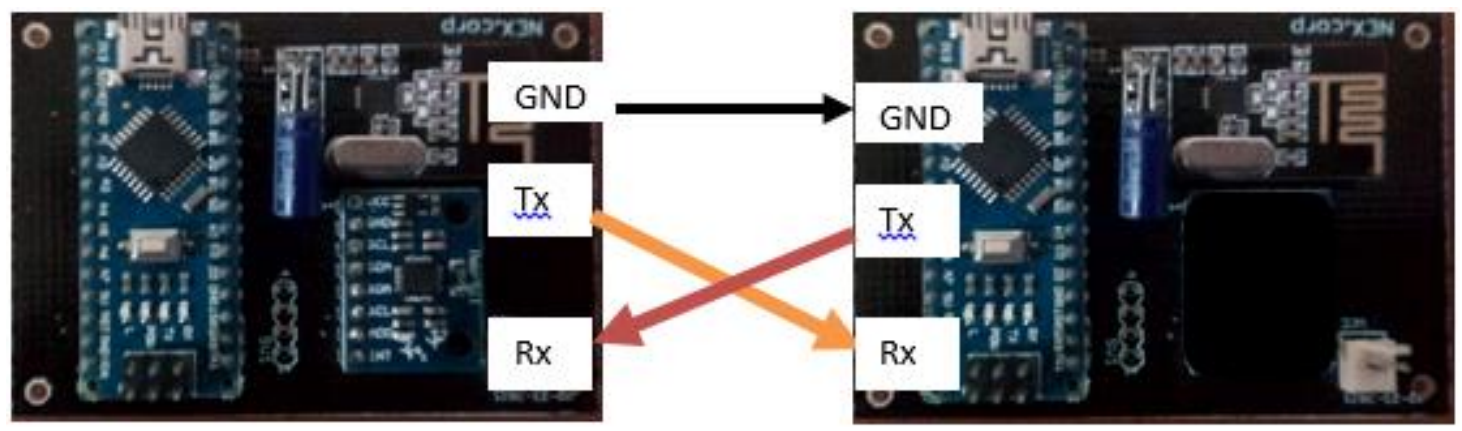

Gambar 6. Wiring diagram UART

Skematik diagram dan realisasi sistem tungkai atas ditunjukkan pada Gambar 7 dan Gambar 8. Sistem ini dipilih untuk tungkai atas karena memiliki bobot yang lebih berat dan dimensi yang lebih besar sehingga apabila dipasang pada sistem tungkai bawah akan mempengaruhi pada swing phase. Penempatan sensor Gyroscope harus tegak lurus dengan penempatan sensor Gyroscope tungkai bawah agar tidak terjadi kesalahan pada penghitungan sudut lutut. 


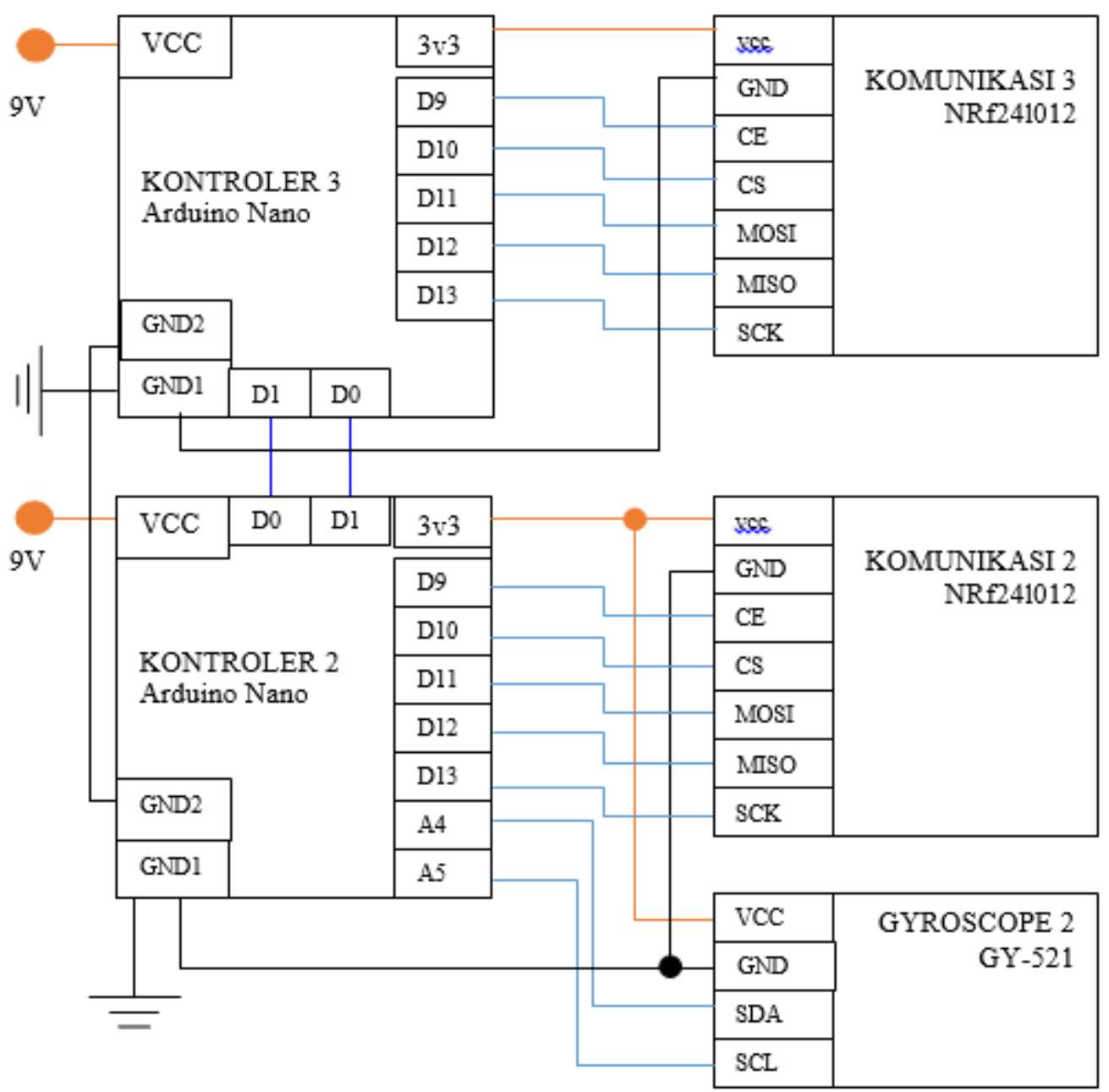

Gambar 7. Skematik diagram sistem tungkai atas

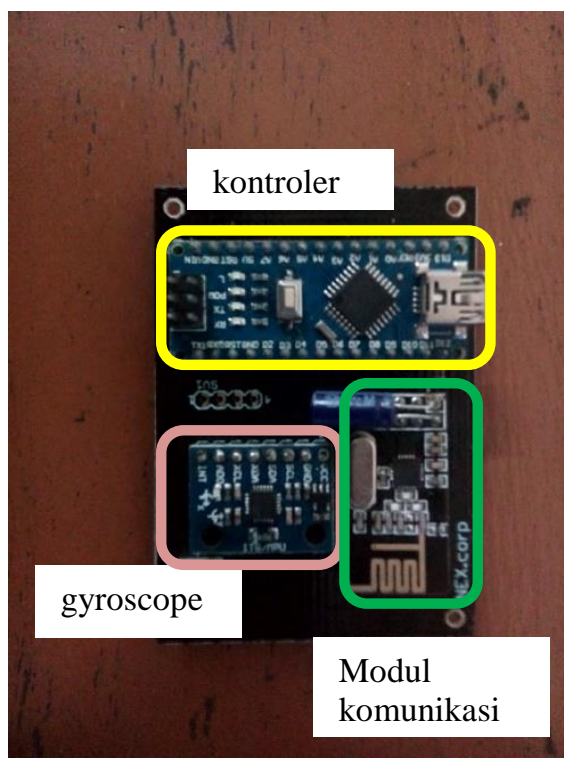

Gambar 8. Realisasi sistem tungkai atas 


\subsubsection{Perancangan Sistem Receiver}

Sistem receiver ini berfungsi menerima data dari sistem tungkai atas lalu menampilkanya pada layar monitor. Sistem ini terdiri dari modul komunikasi NRf24I01, kontroler Arduino Mega dengan chip Atmega 2560 lalu dihubungkan ke PC menggunakan USB port. Skematik diagram dan realisasi dari sistem ini dapat dilihat pada Gambar 9 dan Gambar 10.

Data sudut lutut yang dikirim oleh modul komunikasi 3 (sistem tungkai atas) diterima oleh modul komunikasi receiver untuk diteruskan ke kontroler receiver menggunakan metoda SPI dengan menghubungkan secara berturut - turut pin $\mathrm{CE}, \mathrm{CS}$,MISO,MOSI dan SCK pada modul komunikasi receiver ke pin D9, D10, D50, D51 dan D52 pad kontroler receiver. Lalu data kemudian dikirimkan menuju PC dengan menggunakan fasilitas USB to TTL (TransistorTransistor Logic).

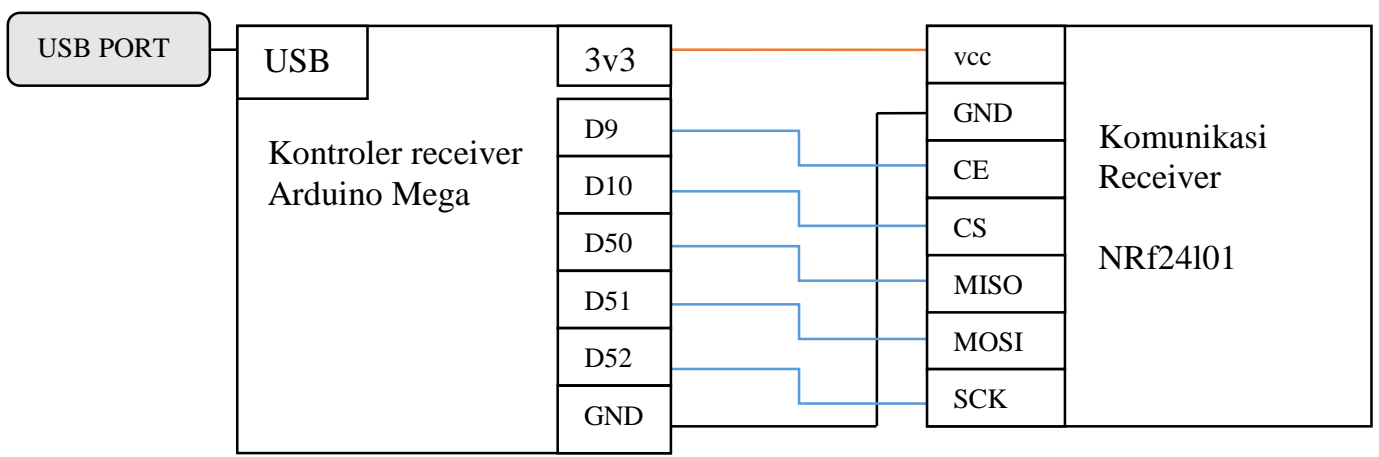

Gambar 9. Skematik diagram sistem receiver

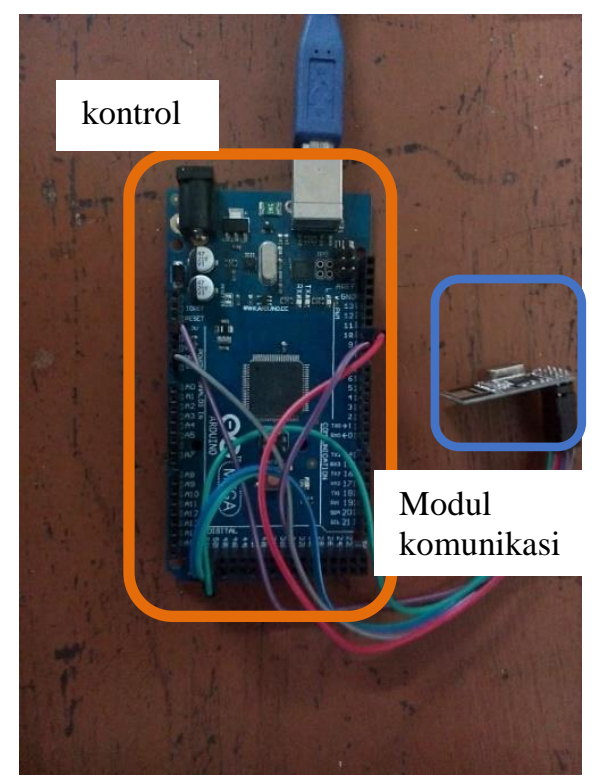

\section{Gambar 10. Realisasi sistem receiver}

\subsubsection{Perancangan Perangkat Lunak}

Pada sistem ini, perancangan perangkat lunak diimplementasikan pada setiap kontroler dan pada PC. Perancangan perangkat lunak pada PC menggunakan aplikasi Arduino IDE Serial Monitor yang akan digunakan sebagai display dari hasil pengukuran. Perancangan perangkat lunak, pada mikrokontroler menggunakan bahasa pemrograman campuran $\mathrm{C}++$ dan C menggunakan aplikasi IDE (Integrated Development Enviroment) dari Arduino. 
Diagram alir dari proses - proses tersebut dapat dilihat pada Gambar 11. Secara umum terdapat 4 (empat) proses komputasi yang dilakukan pada sistem ini. Proses -proses tersebut adalah:

1. Initiating sistem melakukan inisiasi protokol komunikasi, konfigurasi sensor dan menentukan faktor kalibrasi.

2. Reading sensor measurementadalah membaca data hasil pengukuran Gyroscope.

3. Processing sensor measurement into angle adalah melakukan perhitungan matematis untuk mendapatkan data sudut lutut.

4. Display adalah menampilkan data sudut lutut pada komputer.

Proses yang pertama hingga proses yang ketiga terjadi di dalam mikrokontroler Arduino Mega ADK (ATmega 2560) lalu data ditampilkan di layar monitor.

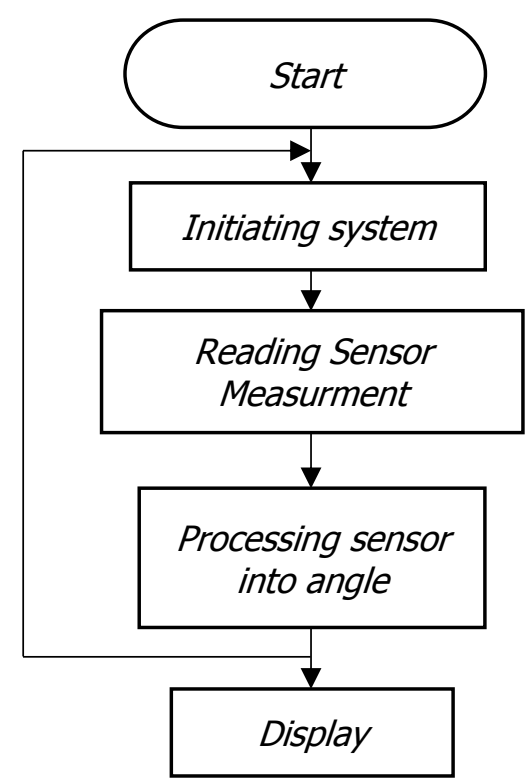

Gambar 11. Flowchart program secara umum

\subsection{Realisasi Seluruh Sistem}

Setelah merealisasikan seluruh sistem selanjutnya kedua sistem (sistem tungkai bawah dan sistem tungkai atas) tersebut ditempelkan pada Goniometer sebagai sudut aktualnya dan ditempelkan pada acrylic sebagai alat untuk mensimulasikan pergerakan lutut. Realisasi keseluruhan sistem alat ukur ditampilkan pada Gambar 12. 

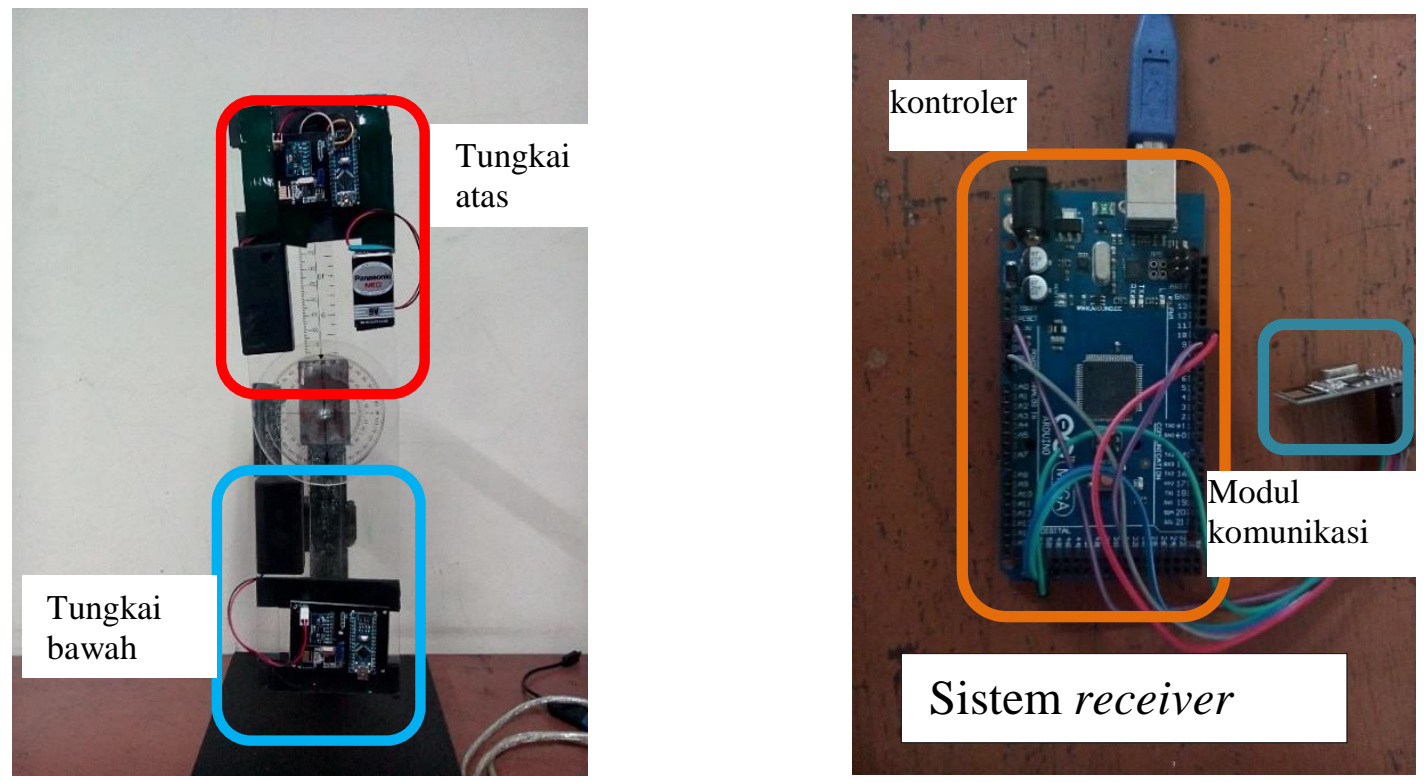

Gambar 12. Realisasi seluruh sistem

\subsection{Metodologi Pengujian Sistem}

Pengujian dilakukan dengan menempelkan kedua sistem ke Goniometer yang ditempelkan pada akrilik sebagai ilustrasi dari pergerakan sudut lutut. Kemudian pengujian dilakukan terhadap kedua sistem secara bergantian dengan cara memutar tungkai dari 180 derajat sampai 50 derajat dengan perubahan 5 derajat ke arah CCW (Counter Clock Wise) setelah itu ke arah CW (Clock Wise) untuk tungkai atas dengan kondisi tungkai bawah pada posisi tegak lurus dan CW lalu CCW untuk tungkai bawah dengan posisi tungkai atas tegak lurus. Ilustrasi pengujian ditunjukkan pada Gambar 13.

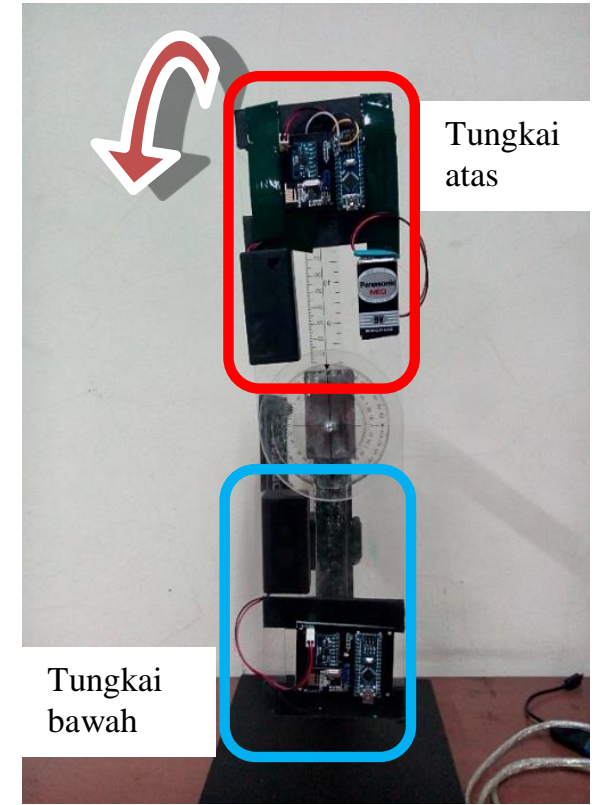

(a)

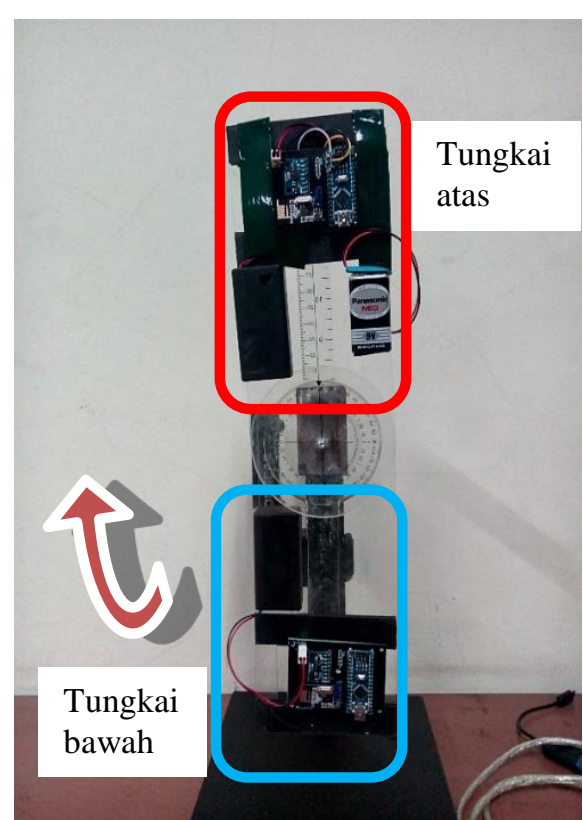

(b)

Gambar 13. (a) Pengujian sistem tungkai atas; (b) Pengujian sistem tungkai bawah 
Pengambilan data diambil dengan cara membandingkan nilai sudut yang tertera pada layar monitor dan nilai yang tertera pada Goniometer, kemudian data diolah menjadi nilai akurasi dan presisi dengan persamaan-persamaan matematis sebagai berikut:

$$
\begin{gathered}
\text { rata }- \text { rata }=\frac{\sum_{x=1}^{3}(\text { pengujian }(x) c c w+\text { pengujian }(x) c w)}{6} \\
\text { error }=(\text { rata }- \text { rata })-\text { nilai aktual } \\
\text { presisi }=\frac{\sum_{x=1}^{3}(\mid \text { pengujian }(x) c c w-(\text { rata }- \text { rata })|+| \text { pengujian }(x) c w-(\text { rata }- \text { rata }) \mid)}{6} \\
\text { rata }- \text { rata presisi }=\frac{\text { presisi }}{\text { Epengujian sudut }}
\end{gathered}
$$

Untuk menguji kehandalan alat maka dicari nilai histerisis sebagai berikut

$$
\begin{gathered}
\text { histerisis }=\frac{\sum_{x=1}^{3}(\mid \text { pengujian }(x) c c w-\text { pengujian }(x) c w \mid)}{6} \\
\text { rata }- \text { rata histerisis }=\frac{\text { histerisis }}{\text { इpengujian persudut }}
\end{gathered}
$$

Pengujian juga dilakukan terhadap komunikasi wireless untuk melihat persentase keberhasilan sistem receiver menerima data yang dikirimkan oleh sistem tungkai atas. Pada penelitian ini sistem receiver hanya mencuplik setengah dari data yang dikirim oleh sistem tungkai atas untuk mendapatkan data yang tidak terlalu besar. Pengujian dilakukan dengan cara mengirimkan sembarang data sudut dengan aplikasi terminal dan menghitung data yang diterima oleh receiver dengan aplikasi Docklight v2 (Gambar 14).

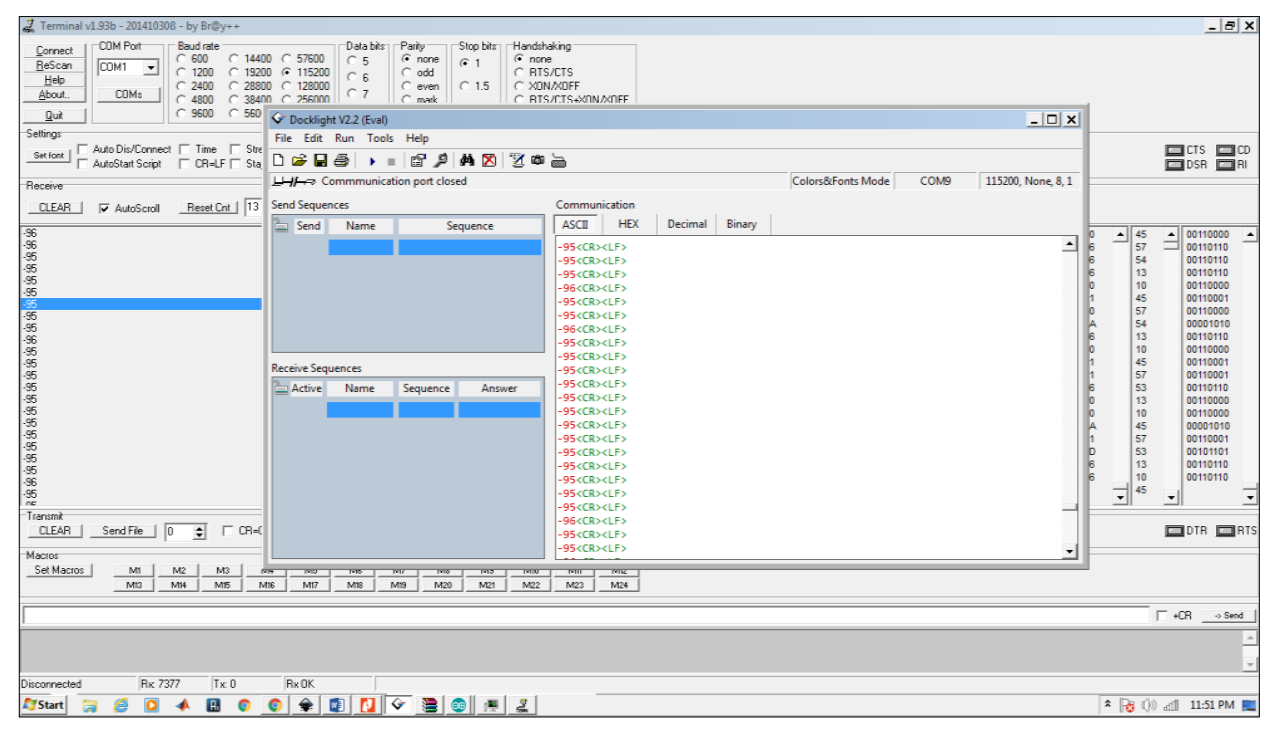

\section{Gambar 14. Pengujian sistem receiver}

Data sudut yang diterima dari sistem tungkai atas kemudian dihitung persentasenya untuk mendapatkan persentase data yang diterima dengan menggunakan Persamaan (9).

$$
\begin{gathered}
\text { data yang diterima }=\frac{\text { data masuk }}{\text { data } \text { kirim }} \times 100 \% \\
\text { Jurnal ELKOMIKA-41 }
\end{gathered}
$$




\section{HASIL PENGUJIAN DAN ANALISIS}

\subsection{Pengujian Sistem Tungkai Bawah}

Hasil dari pengukuran sudut tungkai bawah berdasarkan metoda pengujian disajikan dalam Tabel 1.

Tabel 1. Tabel pengujian bagian sistem tungkai bawah

\begin{tabular}{|c|c|c|c|c|c|c|c|c|}
\hline \multicolumn{9}{|c|}{ Sistem Tungkai Bawah } \\
\hline \multirow{2}{*}{$\begin{array}{c}\text { Aktual } \\
\left({ }^{\circ}\right)\end{array}$} & \multicolumn{2}{|c|}{1} & \multicolumn{2}{|c|}{2} & \multicolumn{2}{|c|}{3} & \multirow{2}{*}{$\begin{array}{c}\text { rata- } \\
\text { rata }\left({ }^{\circ}\right)\end{array}$} & \multirow{2}{*}{$\begin{array}{c}\text { Error } \\
\left({ }^{\circ}\right)\end{array}$} \\
\hline & $\operatorname{Ccw}\left({ }^{\circ}\right)$ & $\mathrm{Cw}\left({ }^{\circ}\right)$ & $\operatorname{Ccw}\left({ }^{\circ}\right)$ & $\mathrm{Cw}\left({ }^{\circ}\right)$ & $\operatorname{Cow}\left({ }^{\circ}\right)$ & $\operatorname{Cw}\left({ }^{\circ}\right)$ & & \\
\hline 180 & 179 & 179 & 179 & 180 & 179 & 179 & 179 & 1 \\
\hline 175 & 173 & 172 & 173 & 173 & 174 & 173 & 173 & 2 \\
\hline 170 & 170 & 169 & 168 & 169 & 169 & 168 & 169 & 1 \\
\hline 165 & 164 & 162 & 162 & 164 & 163 & 164 & 163 & 2 \\
\hline 160 & 161 & 159 & 158 & 159 & 160 & 159 & 159 & 1 \\
\hline 155 & 154 & 154 & 154 & 154 & 155 & 154 & 154 & 1 \\
\hline 150 & 150 & 149 & 149 & 149 & 150 & 149 & 149 & 1 \\
\hline 145 & 144 & 144 & 144 & 145 & 144 & 144 & 144 & 1 \\
\hline 140 & 140 & 139 & 139 & 140 & 140 & 139 & 140 & 1 \\
\hline 135 & 134 & 135 & 135 & 135 & 135 & 135 & 135 & 0 \\
\hline 130 & 129 & 130 & 129 & 129 & 131 & 131 & 130 & 0 \\
\hline 125 & 126 & 126 & 125 & 125 & 126 & 127 & 126 & 1 \\
\hline 120 & 122 & 121 & 121 & 121 & 121 & 123 & 122 & 2 \\
\hline 115 & 117 & 117 & 117 & 118 & 116 & 117 & 117 & 2 \\
\hline 110 & 113 & 112 & 110 & 113 & 111 & 113 & 112 & 2 \\
\hline 105 & 109 & 109 & 108 & 108 & 107 & 109 & 108 & 3 \\
\hline 100 & 107 & 104 & 103 & 106 & 104 & 106 & 105 & 5 \\
\hline 95 & 104 & 106 & 102 & 104 & 101 & 104 & 104 & 9 \\
\hline 90 & 103 & 105 & 102 & 103 & 99 & 102 & 102 & 12 \\
\hline 85 & 75 & 79 & 78 & 78 & 75 & 75 & 77 & 8 \\
\hline 80 & 73 & 74 & 74 & 75 & 74 & 73 & 74 & 6 \\
\hline 75 & 68 & 69 & 69 & 70 & 70 & 70 & 69 & 6 \\
\hline 70 & 64 & 65 & 65 & 68 & 65 & 66 & 66 & 5 \\
\hline 65 & 61 & 61 & 62 & 62 & 61 & 62 & 62 & 4 \\
\hline 60 & 57 & 57 & 57 & 57 & 56 & 57 & 57 & 3 \\
\hline 55 & 52 & 54 & 53 & 53 & 52 & 52 & 53 & 2 \\
\hline 50 & 49 & 49 & 48 & 48 & 48 & 48 & 48 & 2 \\
\hline
\end{tabular}

Untuk melihat perbandingan nilai rata-rata pengukuran sudut tungkai bawah dan nilai aktual maka data tersebut disajikan dalam bentuk grafik seperti pada Gambar 14. 


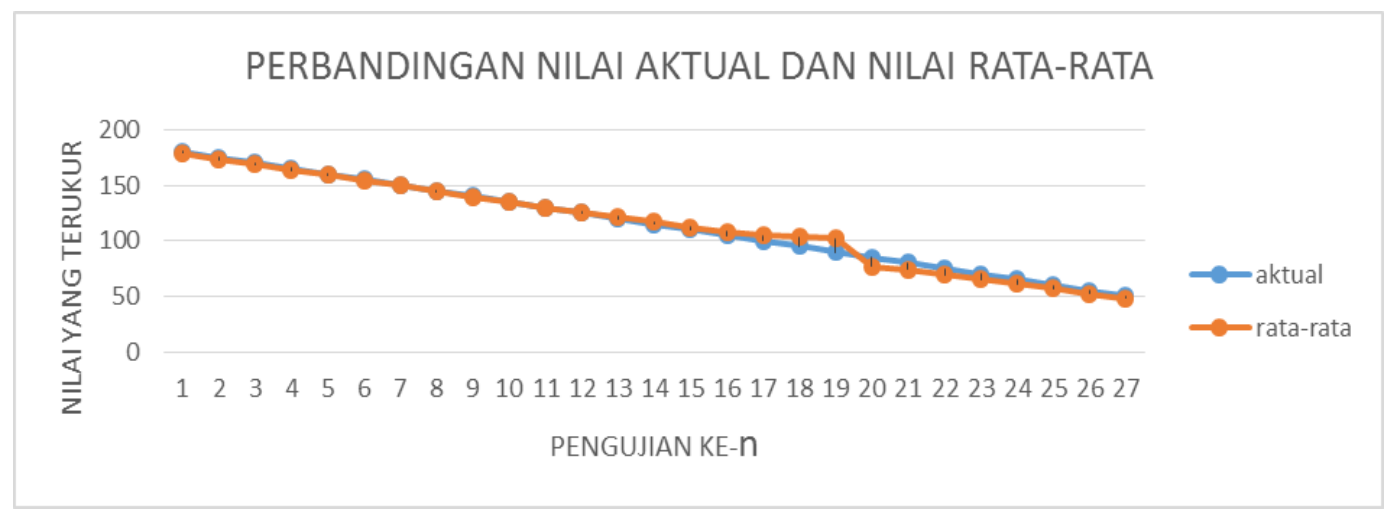

Gambar 15. Grafik perbandingan nilai aktual dan nilai rata-rata tungkai bawah

Terlihat dalam Gambar 15 bahwa nilai aktual dan nilai rata-rata sudut tungkai bawah yang terukur cukup berhimpit. Nilai rata - rata tungkai bawah mulai tidak sesuai dengan nilai aktual yang terukur pada saat pengukuran sudut 95 derajat - 85 derajat. Untuk melihat distribusi nilai error pada pengukuran setiap sudut maka data nilai error terhadap sudut lutut disajikan dalam bentuk grafik seperti ditunjukkan pada Gambar 16.

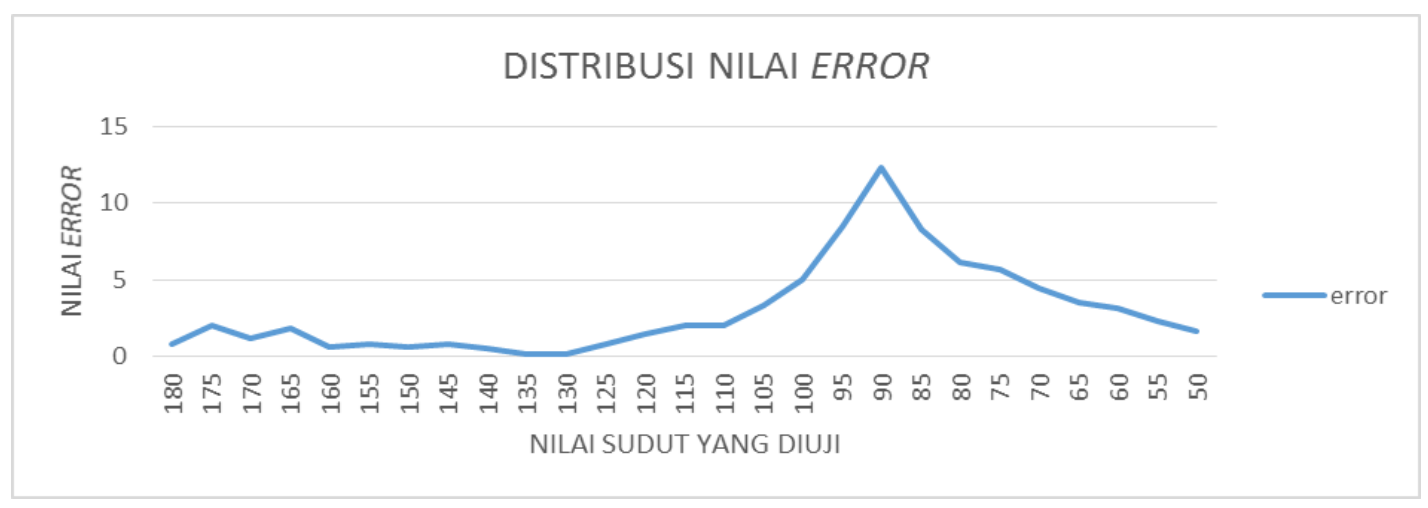

Gambar 16. Nilai Error Pada Tiap Sudut Tungkai Bawah

Nilai error paling besar terjadi ketika alat mengukur sudut 90 derajat yakni sebesar 12 derajat, nilai error yang melebihi 5 derajat terjadi pada saat pengukuran $95-75$ derajat. Berdasarkan rumus yang terdapat dalam metoda pengujian sistem dan data yang diperoleh maka sistem tungkai bawah mempunyai spesifikasi sebagai berikut:

1. Rata-rata error $=3^{\circ}$

2. Rata-rata presisi $=10$

3. Rata-rata Histerisis $=0.9$

Error pada saat pengukuran terjadi karena sensor Gyroscope sangat sensitive terhadap getaran yang terjadi di sekitar lokasi pengujian sistem sehingga nilai yang ditampilkan dalam sistem receiver tidak stabil. Error pada saat pengukuran sudut $100-75$ derajat diakibatkan perubahan nilai percepatan sudut sumbu y (Pitch) dari positif menjadi negatif pada saat sudut tungkai bawah mendekati 90 derajat sehingga terjadi kesalahan perhitungan. Kesalahan dalam membaca Goniometer juga mempengaruhi nilai error, presisi dan histerisis.

\subsection{Pengujian Sistem Tungkai Atas}

Dari hasil pengujian sistem tungkai atas seperti pada metode pengujian, didapatkan hasil sebagai berikut yang ditampilkan dalam Tabel 2. 
Tabel 2. Tabel hasil pengujian sistem tungkai atas

\begin{tabular}{|c|c|c|c|c|c|c|c|c|}
\hline \multicolumn{9}{|c|}{ Sistem Tungkai Atas } \\
\hline \multirow{2}{*}{$\begin{array}{c}\text { Aktual } \\
\left({ }^{\circ}\right)\end{array}$} & \multicolumn{2}{|c|}{ Pengujian 1} & \multicolumn{2}{|c|}{ Pengujian 2} & \multicolumn{2}{|c|}{ Pengujian $\mathbf{3}$} & \multirow{2}{*}{$\begin{array}{c}\text { rata- } \\
\text { rata }\left(^{\circ}\right)\end{array}$} & \multirow{2}{*}{$\begin{array}{c}\text { Error } \\
\left({ }^{\circ}\right)\end{array}$} \\
\hline & $\operatorname{Ccw}\left({ }^{\circ}\right)$ & $\operatorname{Cw}\left({ }^{\circ}\right)$ & $\operatorname{Ccw}\left({ }^{\circ}\right)$ & $\operatorname{Cw}\left({ }^{\circ}\right)$ & $\operatorname{Ccw}\left({ }^{\circ}\right)$ & $\operatorname{Cw}\left({ }^{\circ}\right)$ & & \\
\hline 180 & 181 & 181 & 181 & 181 & 181 & 180 & 181 & 1 \\
\hline 175 & 175 & 176 & 175 & 176 & 176 & 175 & 176 & 1 \\
\hline 170 & 170 & 170 & 170 & 170 & 171 & 170 & 170 & 0 \\
\hline 165 & 166 & 165 & 166 & 166 & 165 & 166 & 166 & 1 \\
\hline 160 & 161 & 160 & 160 & 161 & 160 & 161 & 161 & 1 \\
\hline 155 & 156 & 155 & 155 & 155 & 155 & 157 & 156 & 1 \\
\hline 150 & 151 & 151 & 151 & 150 & 151 & 150 & 151 & 1 \\
\hline 145 & 146 & 145 & 145 & 146 & 145 & 146 & 146 & 1 \\
\hline 140 & 141 & 140 & 141 & 140 & 140 & 141 & 141 & 1 \\
\hline 135 & 136 & 134 & 135 & 135 & 135 & 136 & 135 & 0 \\
\hline 130 & 130 & 130 & 130 & 131 & 130 & 131 & 130 & 0 \\
\hline 125 & 125 & 126 & 125 & 125 & 124 & 126 & 125 & 0 \\
\hline 120 & 120 & 120 & 120 & 120 & 120 & 120 & 120 & 0 \\
\hline 115 & 116 & 115 & 115 & 115 & 115 & 116 & 115 & 0 \\
\hline 110 & 110 & 111 & 110 & 110 & 111 & 110 & 110 & 0 \\
\hline 105 & 106 & 106 & 106 & 106 & 106 & 106 & 106 & 1 \\
\hline 100 & 102 & 100 & 100 & 102 & 103 & 101 & 101 & 1 \\
\hline 95 & 97 & 97 & 97 & 97 & 100 & 100 & 98 & 3 \\
\hline 90 & 92 & 95 & 93 & 85 & 83 & 97 & 91 & 1 \\
\hline 85 & 80 & 82 & 86 & 81 & 80 & 80 & 82 & 4 \\
\hline 80 & 76 & 76 & 75 & 76 & 75 & 75 & 76 & 5 \\
\hline 75 & 71 & 71 & 71 & 71 & 70 & 72 & 71 & 4 \\
\hline 70 & 66 & 67 & 66 & 67 & 66 & 67 & 67 & 4 \\
\hline 65 & 59 & 61 & 62 & 62 & 63 & 64 & 62 & 3 \\
\hline 60 & 55 & 55 & 56 & 58 & 57 & 58 & 57 & 4 \\
\hline 55 & 51 & 51 & 51 & 50 & 52 & 52 & 51 & 4 \\
\hline 50 & 46 & 46 & 46 & 46 & 47 & 47 & 46 & 4 \\
\hline
\end{tabular}

Untuk melihat kesesuaian nilai aktual dan nilai rata-rata pengukuran sudut tungkai atas maka untuk nilai rata-rata pengukuran dibandingkan dengan nilai aktual dalam bentuk grafik seperti ditunjukkan pada Gambar 17. 


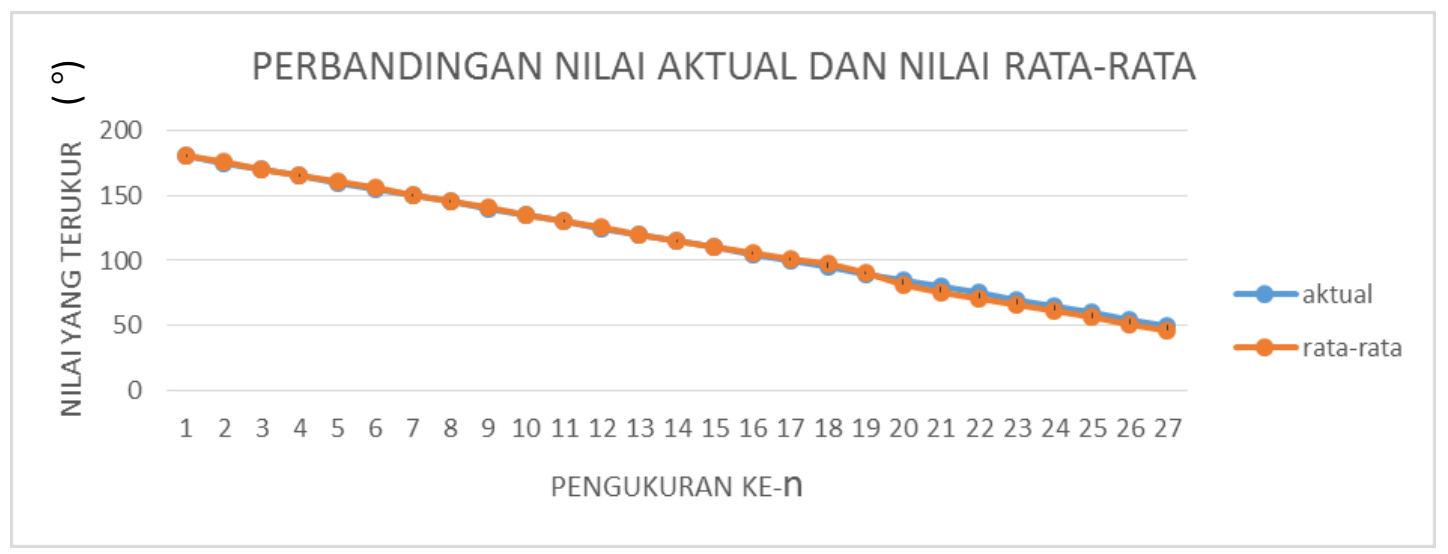

Gambar 17. Grafik perbandingan nilai aktual dan nilai rata-rata sistem tungkai atas

Perbandingan nilai rata-rata pengukuran dan nilai aktual pada pengujian sistem tungkai atas cukup berhimpit. Dengan demikian pengukuran sudut tungkai atas mendekati nilai aktualnya. Untuk mengetahui distribusi nilai error, data nilai error disajikan dalam bentuk grafik pada Gambar 18. Nilai error pada tiap sudut diplot untuk mengetahui persebaran nilai error pada tiap sudut sistem tungkai atas.

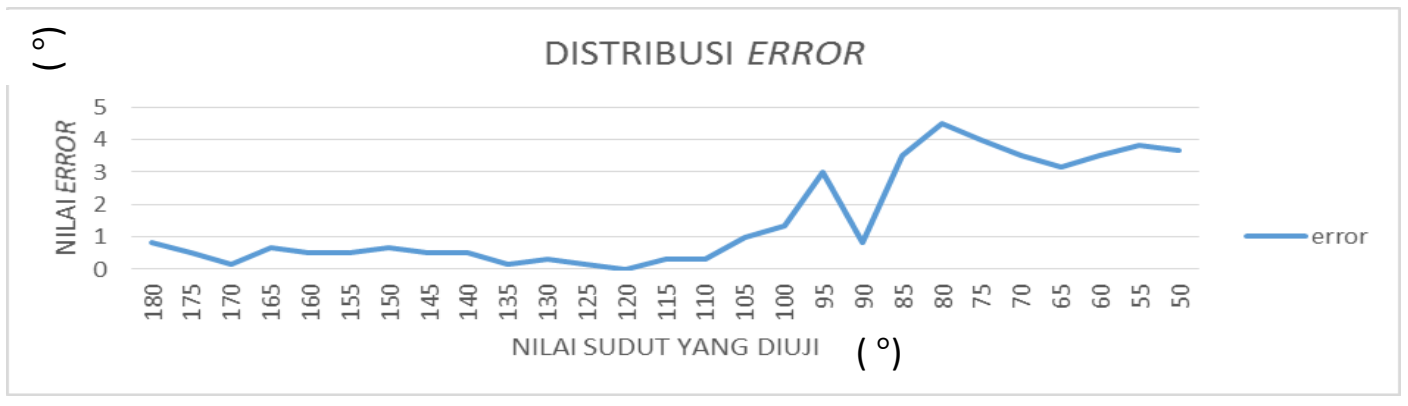

\section{Gambar 18. Grafik nilai error pada tiap sudut tungkai atas}

Nilai error paling besar terjadi ketika alat mengukur sudut 80 derajat yaitu sebesar 4 derajat. Akan tetapi, pada keseluruhan pengukuran sudut tungkai atas, nilai error tidak melebihi 5 derajat. Berdasarkan persamaan yang terdapat dalam metoda pengujian sistem dan data yang diperoleh, maka sistem tungkai atas mempunyai

1. Rata-rata error $=2^{\circ}$

2. Rata-rata presisi $=10$

3. Rata-rata Histerisis $=1$

Error yang terjadi pada saat pengukuran sistem ini diakibatkan kesalahan pembacaan Goniometer dan getaran yang terjadi di sekitar lokasi pengujian. Error pada saat pengukuran sudut 95 sampai 50 derajat dikarenakan perubahan nilai percepatan sudut pada sumbu y (Pitch)yang berubah dari positif ke negatif pada saat sudut tungkai atas mendekati nilai 90 derajat sehingga mempengaruhi nilai sudut tungkai atas.

\subsection{Pengujian Sistem Receiver}

Hasil pengujian sistem receiver ditampilkan pada Tabel 3. Dari hasil pengujian terhadap sistem receiver didapatkan hasil data yang diterima rata-rata $51 \%$ sesuai dengan yang diharapkan pada penelitian yaitu setengah dari data yang dikirimkan. Hal ini dikarenakan sistem receiver dirancang hanya mencuplik setengah dari data yang dikirim oleh bagian transmitter. 
Tabel 3. Tabel pengujian sistem receiver

\begin{tabular}{|c|c|c|}
\hline $\begin{array}{c}\text { Jumlah data } \\
\text { yang dikirim }\end{array}$ & $\begin{array}{c}\text { Jumlah data } \\
\text { yang diterima }\end{array}$ & $\begin{array}{c}\text { Persentase data } \\
\text { yang diterima (\%) }\end{array}$ \\
\hline 109 & 57 & 52 \\
\hline 101 & 54 & 53 \\
\hline 104 & 53 & 50 \\
\hline \multicolumn{2}{|c|}{ Rata-rata persentase data yangditerima } & 51 \\
\hline
\end{tabular}

Pengujian dilakukan pada jarak 1 meter indoor antara bagian transmitter dan bagian receiver. Maksimum jarak jangkauan tanpa antena eksternal yang dimiliki oleh modul komunikasi ini adalah sejauh 30 meter indoor 100 meter outdoor (Fajriansyah, dkk, 2016). Pencuplikan data sudut lutut yang diterima dilakukan dengan mengubah nilai delay time pada kontroler receiver sehingga data sudut lutut yang diterima tidak stabil.

\section{KESIMPULAN DAN SARAN}

\subsection{Kesimpulan}

Dari hasil perhitungan dan pengujian terhadap alat ukur sudut tekuk lutut dapat diambil beberapa kesimpulan sebagai berikut:

1. Simpangan rata-rata hasil pengukuran alat adalah 2 derajat untuk tungkai atas dan 3 derajat untuk tungkai bawah.

2. Pada sistem tungkai atas, nilai error paling besar terjadi pada sudut 90 derajat dan sudut 80 derajat.

3. Sistem tungkai bawah memiliki error lebih besar dari 5 derajat pada saat pengukuran sudut 100 derajat sampai dengan 75 derajat.

4. Sistem tungkai atas tidak memiliki simpangan yang lebih besar dari 5 derajat.

5. Sistem alat ukur sudut yang telah diimplementasikan mampu mengukur sudut dari 180 derajat (posisi kaki tegak lurus) sampai sudut 55 derajat.

6. Komunikasi wireless untuk pengiriman data sudut dapat digunakan dengan baik ditandai dengan hasil pengiriman data yang menunjukkan $51 \%$ paket data diterima telah diterima dengan baik sesuai dengan metoda pencuplikan data yang dirancang.

\subsection{Saran}

Adapun saran untuk pengembangan lebih lanjut sebagai berikut :

1. Untuk mengurangi error pada saat transisi pengukuran perlu diambil data percepatan sudut pada sumbu y sebagai referensi agar tepat pada nilai 90 derajat.

2. Untuk mendapatkan nilai sudut disarankan untuk menggunakan nilai Yaw.

3. Agar dilakukan pengujian di tempat yang memiliki getaran yang kecil.

4. Letak kedua sensor Gyroscope harus sejajar agar lebih tepat dalam pengukuran.

5. Pada pengujian selanjutnya perlu dilakukan pengujian dengan menggerakan kedua tungkai kaki untuk mengukur sudut lutut. 


\section{DAFTAR RUJUKAN}

Derry. (2016). Study on Inertial Measurement Unit Sensor for Knee Angle Measurement. Bachelor Thesis. Tangerang : Swiss German University (SGU) Indonesia.

Faried. (2012). Pengaruh Ostheoporosis Terhadap Pola Jalan (Gait) Pada Usia 65-70 Tahun. UMSU.

Fajriansyah, B., Ichwan, M., Susana, R. (2016). Evaluasi Karakteristik XBee Pro dan nRF24L01+ sebagai Transceiver Nirkabel. Jurnal Elkomika. 4(1): 83-97.

Kaufman, K.R., Hughes, C., Morrey, B.F., M., An, K-N. (2001). Gait characteristics of patients with knee osteoarthritis. Journal of Biomechanics 34:907-915.

McCarthy, I, Hodgins, D., Mor, A., Elbaz, A., Segal, G. (2013). Analysis of knee flexion characteristics and how they alter with the onset of knee osteoarthritis: a case control study. BMC Musculoskelet. Disord. 14. 169.

Taryana, N., Nataliana, D., Ananda, A. R.. (2015). Pendeteksi Sikap pada Model Wahana Terbang menggunakan Inertial Measurement Unit. Jurnal Elkomika. 3(1):16-37. 